\title{
IRRECONCILABLE DIFFERENCES: HOW SANCHEZ-LLAMAS $v$. OREGON UNDERMINES ARTICLE 36 OF THE VIENNA CONVENTION ON CONSULAR RELATIONS
}

\author{
Eric Rosenfeld
}

For over 150 years, the principle of comity has played a crucial role in American legal jurisprudence in the arena of international law. ${ }^{1}$ Comity is the "practice among political entities (as nations, states, or courts of different jurisdictions), involving ... mutual recognition of legislative, executive, and judicial acts." ${ }^{2}$ At the highest level of generality, comity encourages international judicial courtesy and respect for foreign legal values. ${ }^{3}$ With regard to interstate relations, it has shaped the uniquely American doctrine of act of state as well as the international understanding of foreign sovereign immunity. ${ }^{4}$ Against the backdrop of Cold War diplomacy in the 1960s, comity also fostered the Vienna Convention on Consular Relations ${ }^{5}$ (VCCR), a treaty that seeks to regulate relations between individual nations and foreign consular officials. The VCCR governs diplomatic protocol such as the establishment and conduct of consular relations and the privileges and immunities of consular officers and offices from the laws of the "receiving State" (the country where the foreign consular office has been established) ${ }^{6}$ Its adoption was arguably "the single most important event in the entire history of the consular institution."”

\footnotetext{
* $\quad$ Eric Rosenfeld currently practices at Dechert LLP in the firm's Philadelphia office. He received a J.D. from the University of Pittsburgh in 2008 and a B.A. in History from the Schreyer Honors College of the Pennsylvania State University in 2004.

1. See, e.g., Hilton v. Guyot, 159 U.S. 113 (1895).

2. Black's Law Dictionary 284 (8th ed. 2004).

3. See Hilton, 159 U.S. at 163-64:

"Comity," in the legal sense, is neither a matter of absolute obligation, on the one hand, nor of mere courtesy and good will, upon the other. But it is the recognition which one nation allows within its territory to the legislative, executive or judicial acts of another nation, having due regard both to international duty and convenience, and to the rights of its own citizens, or of other persons who are under the protection of its laws.

4. See Somportex, Ltd. v. Phila. Chewing Gum Corp., 453 F.2d 435 (3d Cir. 1971).

5. Vienna Convention on Consular Relations, Apr. 24, 1963, 21 U.S.T. 77, 596 U.N.T.S. 261 [hereinafter VCCR].

6. Luke T. Lee, Consular Law and Practice 26 (2d ed. 1991).

7. Id.
} 
On an individual scale, notions of comity and reciprocity inspired Article 36 of the VCCR, the most influential provision with respect to private parties. ${ }^{8}$ This Article discusses how the 2006 United States Supreme Court SanchezLlamas $^{9}$ decision renders Article 36 functionally irrelevant in American courts. Article 36 governs relations between a sending state's consulate and foreign nationals arrested in a receiving state. ${ }^{10}$ The provision proclaims twin rights of foreign nationals arrested in signatory countries, of which the United States is one of some 170 participating nations. ${ }^{11}$ Article 36 first provides that "if [the detainee] so requests, the competent authorities of the receiving State shall, without delay, inform the consular post of the sending State if, within its consular district, a national of that State is arrested or committed to prison or to custody pending trial or is detained in any other manner." 12 In other

8. In its entirely, Article 36 states:

1. With a view to facilitating the exercise of consular functions relating to nationals of the sending State:

(a) consular officers shall be free to communicate with nationals of the sending State and to have access to them. Nationals of the sending State shall have the same freedom with respect to communication with and access to consular officers of the sending State; (b) if he so requests, the competent authorities of the receiving State shall, without delay, inform the consular post of the sending State if, within its consular district, a national of that State is arrested or committed to prison or to custody pending trial or is detained in any other manner. Any communication addressed to the consular post by the person arrested, in prison, custody or detention shall also be forwarded by the said authorities without delay. The said authorities shall inform the person concerned without delay of his rights under this sub-paragraph;

(c) consular officers shall have the right to visit a national of the sending State who is in prison, custody or detention, to converse and correspond with him and to arrange for his legal representation. They shall also have the right to visit any national of the sending State who is in prison, custody or detention in their district in pursuance of a judgment. Nevertheless, consular officers shall refrain from taking action on behalf of a national who is in prison, custody or detention if he expressly opposes such action.

2. The rights referred to in paragraph 1 of this Article shall be exercised in conformity with the laws and regulations of the receiving State, subject to the proviso, however, that the said laws and regulations must enable full effect to be given to the purposes for which the rights accorded under this Article are intended.

VCCR, supra note 5, art. 36.

9. Sanchez-Llamas v. Oregon, 548 U.S. 331 (2006). In the fall of 2007, the U.S. Supreme Court granted certiorari in Medellin v. Texas (06-984). The Court issued a decision in the spring of 2008. Medellin v. Texas, 128 S.C. 1346 (2008). The Court decided certain elements that Sanchez-Llamas left open - notably holding that Article 36 of the Vienna Convention is not self-executing — while leaving other issues unresolved. The next development will likely be a congressional initiative to pass implementing legislation for Article 36.

10. The "sending State" is the nation of the arrestee; the "receiving State" is the arresting nation. United States v. Emuegbunam, 268 F.3d 377, 388 n.3 (6th Cir. 2001).

11. Sanchez-Llamas, 548 U.S. at 336-38.

12. VCCR, supra note 5, art. 36(1)(b). 
words, if a foreign national is detained in another country by the authorities of that country, the authorities of the receiving state must promptly notify the consulate of the sending state if the detainee so requests. Second, "[t]he said authorities shall inform the person concerned without delay of his rights under this sub-paragraph."13 This prong requires the authorities to inform the detainee of his underlying right to consular notice. Therefore, Article 36 confers upon detainees the substantive right of consular notice which it then vindicates with the procedural requirement that the detaining authorities must inform said detainees of the right to consular notice.

The right to consular notice under Article 36 has the potential for widespread impact in the United States given the large number of non-citizens incarcerated in American correctional facilities. According to the Department of Justice, federal and state prisons held over 91,000 non-citizens during $2005 .{ }^{14}$ Non-citizens composed over $10 \%$ of the state prison population in California, New York, Arizona, and Nevada. ${ }^{15}$ With such a large population potentially covered by the provisions of Article 36, it would be reasonable to assume that the procedures and applications surrounding these rights are uniform and established. However, since the United States ratified the VCCR in 1969, enforcement of Article 36 rights has varied widely from case to case and from court to court. ${ }^{16}$

\section{Article 36 in the Supreme Court and the International Court of Justice}

In 1998, almost thirty years after ratification of the VCCR, the Supreme Court issued its first significant decision regarding the right to consular notice under Article 36; however, the Court provided few practical guidelines to American courts concerning the contours of these rights. The defendant in Breard v. Greene $e^{17}$ was charged with rape and murder allegedly without ever being informed of his Article 36 right to consular notice. ${ }^{18}$ In failing to intervene in the defendant's imminent execution, the Court held that it was "clear that Breard procedurally defaulted his claim, if any, under the Vienna

13. Id.

14. Paige M. Harrison \& Allen J. Beck, Bureau of Justice Statistics, U.S. Dep't of Justice, Prison and Jail InMates at Midyear 2005, at 5 (2006), available at http://ojp.usdoj.gov/bjs/pub/ pdf/pjim05.pdf.

15. Id.

16. Sanchez-Llamas, 548 U.S. at 371-72 (Breyer, J., dissenting).

17. 523 U.S. 371 (1998)

18. Id. at 373 . 
Convention by failing to raise that claim in the state courts." 19 Therefore, the Court disposed of the case procedurally without addressing the substantive merit of foreign nationals' Article 36 rights.

In 2001 and 2003, two decisions by the International Court of Justice (ICJ) - the primary judicial organ of the United Nations - attempted to add teeth to the consular notice provision of Article 36 by holding that an "effective" judicial remedy is required for violating the right to consular notice. ${ }^{20}$ These cases, Avena and LaGrand, were later summarized by the Supreme Court as follows:

The LaGrand Case and the Case Concerning Avena and other Mexican Nationals were brought before the ICJ by the governments of Germany and Mexico, respectively, on behalf of several of their nationals facing death sentences in the United States. The foreign governments claimed that their nationals had not been informed of their right to consular notification. They further argued that application of the procedural default rule to their nationals' Vienna Convention claims failed to give "full effect" to the purposes of the Convention, as required by Article 36 . The ICJ agreed, explaining that the defendants had procedurally defaulted their claims "because of the failure of the American authorities to comply with their obligation under Article 36." Application of the procedural default rule in such circumstances, the ICJ reasoned, "prevented [courts] from attaching any legal significance" to the fact that the violation of Article 36 kept the foreign governments from assisting in their nationals' defense. ${ }^{21}$

Notwithstanding the ICJ's interpretation, questions over the body's jurisdictional authority to interpret Article 36 for U.S. courts led to fresh confusion and uncertain import. ${ }^{22}$ Finally, in June 2006, the U.S. Supreme Court in Sanchez-Llamas issued an important ruling concerning the contours of Article 36. In the consolidated appeal, petitioners Moises Sanchez-Llamas of Mexico and Mario Bustillo of Honduras alleged they were never informed of their right to contact their respective consulates after being arrested for unrelated violent crimes. ${ }^{23} \quad$ Both men asserted that their post-arrest incrimination derived at least partly from a lack of consular access. ${ }^{24}$ Although Sanchez-Llamas has yet to be tested widely in lower courts, the

19. Id. at 375 .

20. LaGrand Case (F.R.G. v. U.S.), 2001 I.C.J. 466 (June 27); Case Concerning Avena and Other Mexican Nationals (Mex. v. U.S.), 2004 I.C.J. 128 (Mar. 31).

21. Sanchez-Llamas, 548 U.S. at 352-53 (citations omitted).

22. Id. at 353 .

23. Id. at 340 .

24. Id. 
decision seems to defeat any realistic enforcement of the right to consular notice under Article 36.

Because the text of Article 36 contemplates consular notice in criminal proceedings, most cases in which the issue arises initially occur at the state level. However, Article 36 issues also surface in federal court, primarily in post-conviction habeas corpus proceedings. Although Sanchez-Llamas addresses the application of Article 36 in state court, ${ }^{25}$ federal courts will continue to arbitrate Article 36 claims when future defendants file federal habeas corpus claims that invoke Article 36.

Although the VCCR initially contemplated an interpretative role for the ICJ, in 2005 the United States withdrew from the Optional Protocol conferring this authority upon the ICJ. ${ }^{26}$ Acknowledging this recent diplomatic posture as well as the historical judicial architecture of the VCCR, Justice Breyer's dissent in Sanchez-Llamas apparently reaffirms the self-executing status of Article $36 .{ }^{27}$

The Supreme Court granted certiorari for three questions in SanchezLlamas:

First, does Article 36 create rights that defendants may invoke against the detaining authorities in a criminal trial or in a postconviction proceeding? Second, does a violation of Article 36 require suppression of a defendant's statements to police? Third, may a State, in a postconviction proceeding, treat a defendant's Article 36 claim as defaulted because he failed to raise the claim at trial? ${ }^{28}$

Regarding the first question, although the Court found it "unnecessary to resolve the question [of] whether the Vienna Convention grants individuals enforceable rights," ${ }^{29}$ the practical effect is to do precisely that. By holding that suppression is an inappropriate remedy for Article 36 violations, and that states can apply their normal procedural default rules to Article 36 violation

25. Id. at 337 .

26. Id. at 339 (citations omitted):

Along with the Vienna Convention, the United States ratified the Optional Protocol Concerning the Compulsory Settlement of Disputes. The Optional Protocol provides that "[d]isputes arising out of the interpretation or application of the Convention shall lie within the compulsory jurisdiction of the International Court of Justice [(ICJ)]," and allows parties to the Protocol to bring such disputes before the ICJ. The United States gave notice of its withdrawal from the Optional Protocol on March 7, 2005.

27. Id. at 372 (Breyer, J., dissenting). In the spring of 2008, the Supreme Court issued a ruling in Medellin v. Texas, 128 S. Ct. 1346 (2008). It held that the Article 36 of the VCCR is not self-executing. Id. at 1353.

28. Sanchez-Llamas, 548 U.S. at 337.

29. Id. at 343 . 
claims ${ }^{30}$ the Court made it extremely unlikely that foreign nationals could secure a direct and meaningful remedy for Article 36 violations.

Although the language of Article 36 clearly defines the right to consular access as well as notice of that right, the treaty language itself reveals an underlying tension over how to enforce these provisions. Article 36 declares that its delineated rights "shall be exercised in conformity with the laws and regulations of the receiving State." 31 Yet in other language, this command is "subject to the proviso ... that the said laws and regulations [of the receiving state] must enable full effect to be given to the purposes for which the rights accorded under this Article are intended." ${ }^{32}$ Therefore, Article 36 itself fails to delineate the extent to which implementation of Article 36 rights must conform to the domestic law of the receiving state.

The procedural default doctrine is perhaps the principal obstacle to effective Article 36 violation claims in state court. Procedural default, adopted in federal habeas corpus proceedings and followed by many states, bars a defendant from raising a claim on collateral review that the defendant failed to raise at trial. ${ }^{33}$ Accordingly, a foreign national who fails to assert an Article 36 violation at trial or on appeal may be precluded from subsequently raising an Article 36 challenge at a post-conviction hearing or habeas corpus proceeding. ${ }^{34}$ This remains true even if the reason that the defendant did not originally assert an Article 36 violation stems from the authorities' failure to comply with the notice provision of Article $36 .{ }^{35}$ In other words, a defendant can default on an Article 36 claim even if the reason for not raising the claim was itself the result of an Article 36 violation. ${ }^{36}$

The dissent in Sanchez-Llamas asserts that this seemingly circular application of the procedural default doctrine violates the "full effect" requirement of Article $36 .{ }^{37}$ However, the majority persuasively analogizes to the possibility of defendants defaulting on their Miranda rights even though

\footnotetext{
30. Id. at 337 .

31. VCCR, supra note 5, art. 36(2).

32. Id.

33. In post-conviction hearings, many states follow the general rule in federal habeas cases that "a defendant who fails to raise a claim on direct appeal is barred from raising the claim on collateral review. There is an exception [in federal habeas proceedings] if a defendant can demonstrate both 'cause' for not raising the claim at trial, and 'prejudice' from not having done so." Sanchez-Llamas, 548 U.S. at 351 (citations omitted).

34. Id. at 358 .

35. Id.

36. Id.

37. Id. at 379 (Breyer, J., dissenting).
} 
the reason for the default itself stemmed from an underlying Miranda violation. ${ }^{38}$ Finally, the Court identifies differences between the adversarial system and the inquisitorial system; ${ }^{39}$ the result is to render the dissenting opinion and prior ICJ decisions inapposite. Taken as a whole, the majority decision strips Article 36 of any real authority and drastically undermines the future of the consular notice requirement in U.S. jurisdictions.

Eight years before Sanchez-Llamas, the Court in Breard v. Greene $e^{40}$ faced a similar challenge over whether Article 36 rights are susceptible to the forum's procedural default rules. There the Court held that Article 36 does not trump the procedural default doctrine. ${ }^{41}$ First, the Court observed that "it has been recognized in international law that, absent a clear and express statement to the contrary, the procedural rules of the forum State govern the implementation of the treaty in that State." ${ }^{42}$ The Court continued that while Article 36 is part of a valid federal treaty and therefore the "supreme law of the land," even constitutional rights are subject to procedural default. ${ }^{43}$ If even constitutional rights are subject to procedural default, it follows that nothing is immune from this harsh doctrine. Hence, Article 36 claims are susceptible to procedural default.

Sanchez-Llamas assumes a foundational baseline that the receiving state's "laws and regulations" regulate the meaning of the "full effect" requirement of Article 36. That is, the Court held that the "full effect" of Article 36 rights can and must be vindicated within the framework of the receiving state's "laws and regulations." By framing the issue in this manner, the Court makes Article 36 rights subsidiary to state law and state procedure.

Considering the procedural default system adopted in many states, if defendants fail to raise Article 36 violations at trial or appeal due to the failure of the authorities to inform them of their Article 36 rights, claims of Article 36 violations will typically be relegated to one component of a post-conviction ineffective assistance of council claim or as part of a broader challenge to the voluntariness of a confession. ${ }^{44}$ While it is unclear whether these avenues of relief fulfill the "full effect" intended by the drafters of Article 36, Sanchez-

38. Id. at 358 (majority opinion).

39. Id. at 357 .

40. 523 U.S. 371 (1998).

41. Id. at 375 .

42. Id. (citing Sun Oil Co. v. Wortman, 486 U.S. 717, 723 (1988)); Volkswagenwerk Aktiengesellschaft v. Schlunk, 486 U.S. 694, 700 (1988); Societe Nationale Industrielle Aerospatiale v. U.S. Dist. Ct. for S. Dist. of Iowa, 482 U.S. 522, 539 (1987).

43. Id. at 376 .

44. Sanchez-Llamas, 548 U.S. at 364 n.3 (Ginsburg, J., concurring). 
Llamas leaves room for little else. To the dissent in Sanchez-Llamas and to the ICJ in several recent cases, this is unnecessarily dismissive of Article 36. Whereas the ICJ in Avena ${ }^{45}$ and LaGrand ${ }^{46}$ would require direct application of Article 36 rights, the Supreme Court in Sanchez-Llamas requires only subsidiary enforcement according to state-specific forum law, ${ }^{47}$ the result of which is an emasculated Article 36.

In 2001, the ICJ confronted the "circular Article 36 violation" problem discussed above; the international tribunal ruled that procedural default rules must yield in situations where defendants' procedural default occurred "because of the failure of American authorities to comply with their obligation under Article 36." ${ }^{\prime 4}$ In 2003, the ICJ again held against such application of procedural default rules because it "prevented [courts] from attaching any legal significance" to the fact that underlying Article 36 violations kept the foreign nationals from securing assistance from their home government. ${ }^{49}$ In allowing Article 36 rights to be enforced according to state law and state procedure, Sanchez-Llamas invokes a different theoretical framework than that utilized by ICJ to determine the "full effect" of Article 36 rights. This baseline disparity results as much from the structure of the American adversarial system as it does a preference for domestic law over application of the VCCR. ${ }^{50}$

45. Case Concerning Avena and Other Mexican Nationals (Mex. v. U.S.), 2004 I.C.J. 128, 134 (Mar. 31)

46. LaGrand Case (F.R.G. v. U.S.), 2001 I.C.J. 466, ๆ 91 (June 27).

47. Sanchez-Llamas, 548 U.S. at 356-57.

48. LaGrand, 2001 I.C.J. 466 \91; see also Avena, 2004 I.C.J. 128 \113.

49. LaGrand, 2001 I.C.J. 466991.

50. The Court also questioned the authority of the ICJ generally in interpreting Article 36 :

Nothing in the structure or purpose of the ICJ suggests that its interpretations were intended to be conclusive on our courts. The ICJ's decisions have "no binding force except between the parties and in respect of that particular case." Any interpretation of law the ICJ renders in the course of resolving particular disputes is thus not binding precedent even as to the ICJ itself; there is accordingly little reason to think that such interpretations were intended to be controlling on our courts. The ICJ's principal purpose is to arbitrate particular disputes between national governments. While each member of the United Nations has agreed to comply with decisions of the ICJ "in any case to which it is a party," the Charter's procedure for noncompliance - referral to the Security Council by the aggrieved state-contemplates quintessentially international remedies."

Sanchez-Llamas, 548 U.S. at 354-55 (footnote omitted) (citations omitted). Furthermore, the Court observed that

after [the ICJ decisions], the United States withdrew from the Optional Protocol concerning Vienna Convention disputes. Whatever the effect of Avena and LaGrand before this withdrawal, it is doubtful that our courts should give decisive weight to the interpretation of a tribunal whose jurisdiction in this area is no longer recognized by the United States. 
The ICJ concluded that application of the procedural default rule in certain situations failed to give "full effect" to the purposes of Article 36 because it prevented courts from attaching "legal significance" to the Article 36 violation. $^{51}$ In Sanchez-Llamas, the Supreme Court found this interpretation to be in conflict with the basic framework of the American adversarial system: ${ }^{52}$

Procedural default rules generally take on greater importance in an adversary system such as ours than in the sort of magistrate-directed, inquisitorial legal system characteristic of many of the other countries that are signatories to the Vienna Convention. "What makes a system adversarial rather than inquisitorial is ... the presence of a judge who does not (as an inquisitor does) conduct the factual and legal investigation himself, but instead decides on the basis of facts and arguments pro and con adduced by the parties." In an inquisitorial system, the failure to raise a legal error can in part be attributed to the magistrate, and thus to the state itself. In our system, however, the responsibility for failing to raise an issue generally rests with the parties themselves. ${ }^{53}$

This analysis reveals what form the "full effect" of Article 36 might take in an American state court that adheres to a strict procedural default scheme. With its emphasis on party representation as the primary means of vindicating one's rights, the Supreme Court bolsters the notion that an ineffective assistance of council claim provides the requisite "full effect" to Article 36 rights. Both LaGrand and Avena dispute that this recourse is adequate. ${ }^{54}$ Instead, those cases would require that state court procedural default rules provide a direct remedy for Article 36 violations. ${ }^{55}$ Herein lies what seems to be an irreconcilable difference between the approach taken by the ICJ and the

Id. at 355 .

51. LaGrand, 2001 I.C.J. 466, ๆๆ 90-91.

52. Sanchez-Llamas, 548 U.S. at 356-57 (citations omitted):

This reasoning overlooks the importance of procedural default rules in an adversary system, which relies chiefly on the parties to raise significant issues and present them to the courts in the appropriate manner at the appropriate time for adjudication. Procedural default rules are designed to encourage parties to raise their claims promptly and to vindicate "the law's important interest in the finality of judgments." The consequence of failing to raise a claim for adjudication at the proper time is generally forfeiture of that claim. As a result, rules such as procedural default routinely deny "legal significance"-in the Avena and LaGrand sense- to otherwise viable legal claims.

See also Castro v. United States, 540 U.S. 375, 386 (2003) (Scalia, J., concurring in part and concurring in judgment) ("Our adversary system is designed around the premise that the parties know what is best for them, and are responsible for advancing the facts and arguments entitling them to relief.").

53. Sanchez-Llamas, 548 at 357 (citations omitted).

54. LaGrand, 2001 I.C.J. 466 91; Avena, 2004 I.C.J. 128 \134.

55. Id. 
Supreme Court in Sanchez-Llamas. The disparity likely stems from different legal traditions to which the two courts adhere: the inquisitorial system versus the adversarial system.

Whereas the ICJ would require a direct judicial remedy to satisfy the "full effect" mandate of Article 36, the Supreme Court concluded that subsidiary relief in the form of an ineffective assistance of council claim achieves an acceptable "full effect." In practice, although available procedurally, defendants would find it substantively difficult to meet the requirements of this form of relief. As the Supreme Court identified, "[u]nder our system, an attorney's lack of knowledge does not excuse the defendant's default, unless the attorney's overall representation falls below what is required by the Sixth Amendment. ${ }^{\prime 56}$ Therefore, whereas the ICJ would require a per se remedy for any Article 36 violation, the Supreme Court envisions an Article 36 claim as part of a larger ineffective assistance of council claim based on independent constitutional guarantees. ${ }^{57}$ This result relates directly to the adversarial system's assumption that attorneys play an integral part in vindicating individual rights. Whereas this burden might fall to the state or the judicial process itself in civil law jurisdictions, in common law jurisdictions attorneys carry this responsibility.

In dismissing the ICJ's call for suspending a state's procedural default rules in certain situations - situations where the Article 36 violation itself prevents defendants from becoming aware of their Article 36 rights and asserting them at trial - the Sanchez-Llamas Court analogizes to the similar forfeiture of suspect's rights under Miranda. ${ }^{58}$ Under that line of case law, "police are required to advise suspects that they have a right to remain silent and a right to an attorney." 59 If police fail to give such warnings, and counsel fails to object to this violation, a suspect may not be aware that he ever had such rights until after the trial's conclusion. ${ }^{60}$ "Nevertheless, it is well established that where a defendant fails to raise a Miranda claim at trial, procedural default rules may bar him from raising the claim in a subsequent postconviction proceeding." ${ }^{61}$ Accordingly, if the procedural default doctrine

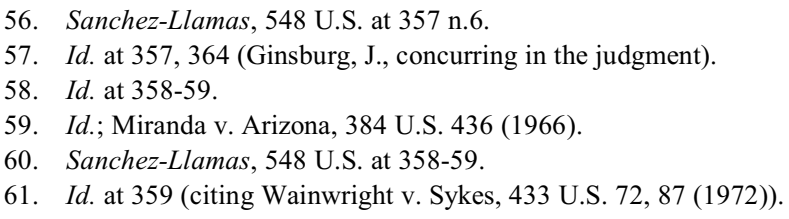


can frustrate even constitutional rights, then it can also hinder lesser rights, such as those accorded by treaty. ${ }^{62}$

Justice Ginsburg, concurring in the judgment of Sanchez-Llamas, observes:

\begin{abstract}
Nothing the State did or omitted to do here "precluded counsel from ... rais[ing] the question of a violation of the Vienna Convention in the initial trial." Had counsel done so, the trial court could have made "appropriate accommodations to ensure that the defendant secure[d], to the extent possible, the benefits of consular assistance." ${ }^{93}$
\end{abstract}

Once again, the action upon which the Court focuses is that of the attorney rather than the authorities who failed to inform the foreign national of the underlying Article 36 rights. ${ }^{64}$ This highlights the disparate treatment such an inquiry receives under the adversarial system versus the inquisitorial system.

The Court's analogy between failure to inform foreign nationals of Article 36 rights and failure to inform defendants of their Miranda rights is internally consistent. However, the harm to potential Article 36 claimants seems particularly harsh considering it is much more likely for an American attorney to be aware of a suspect's Miranda rights than of a foreign national's Article 36 rights, if indeed the attorney is aware of the VCCR at all. For this reason, it is unlikely that a failure to raise an Article 36 violation by itself will rise to the level of ineffective assistance of counsel. More likely, the defendant foreign national would require additional evidence of Sixth Amendment deficiency. ${ }^{65}$ Attempts to vindicate the "full effect" for Article

62. "It is no slight to the Convention to deny petitioner's claims under the same principles we would apply to an Act of Congress, or to the Constitution itself." Id. at 360.

63. Id. at 364 (Ginsburg, J., concurring in the judgment).

64. Id. at $364 \mathrm{n} .3$ (citations omitted):

Furthermore, once [the foreign national in Sanchez-Llamas] became aware of his Vienna Convention rights, nothing prevented him from raising an ineffective-assistance-of-counsel claim predicated on his trial counsel's failure to assert the State's violation of those rights. Through such a claim ... "full effect" could have been given to Article 36, without dishonoring state procedural rules that are compatible with due process. [The foreign national in SanchezLlamas] did not include a Vienna-Convention-based, ineffective-assistance-of-counsel claim along with his direct Vienna Convention claim in his initial habeas petition. He later sought to amend his petition to add an ineffective-assistance-of-counsel claim, but the court held that the amendment did not relate back to the initial pleading. The state court therefore rejected [the] ineffectiveness claim as barred by the applicable state statute of limitations. [The petitioner] did not seek review of that decision in this Court.

65. As the Sanchez-Llamas Court notes, a defendant might also successfully "raise an Article 36 claim as part of a broader challenge to the voluntariness of [the detainee's] statements to police." Id. at 350 (majority opinion). This, too, however, would relegate Article 36 claims to subsidiary status. 
36 violations would once again become subsidiary to other, independent bases of complaint.

\section{Pursuing Article 36 Violations after Sanchez-Llamas}

Considering the harsh result under Sanchez-Llamas, what other substantive recourse is available for Article 36 violations? After stripping Article 36 of meaningful direct judicial enforcement, the Sanchez-Llamas Court offers the following guidelines on how foreign nationals might address Article 36 violations:

Finally, suppression is not the only means of vindicating Vienna Convention rights. A defendant can raise an Article 36 claim as part of a broader challenge to the voluntariness of his statements to police. If he raises an Article 36 violation at trial, a court can make appropriate accommodations to ensure that the defendant secures, to the extent possible, the benefits of consular assistance. Of course, diplomatic avenues - the primary means of enforcing the Convention - also remain open. ${ }^{66}$

The Court engages in judicial minimalism by failing to provide any practical consideration of how these channels might be addressed. Since not many trial courts, including very few appellate courts, have yet to face Article 36 claims after Sanchez-Llamas, the impact of the decision is still undetermined. However, two decisions in late 2006, just several months after the Court decided Sanchez-Llamas, shed some light on what the future holds for Article 36. The first decision is an unpublished opinion by the Sixth Circuit. ${ }^{67}$ The second is a case that ultimately reached the Supreme Court of Pennsylvania. ${ }^{68}$

\section{UNITED STATES V. GARCIA-PEREZ}

United States v. Garcia-Perez involved a Mexican national facing a deportation hearing. ${ }^{69}$ The relevant part of the petitioner's appeal focused on the fact that Washington State authorities never informed him of his right to contact the Mexican consulate pursuant to Article $36 .^{70}$ Since the case arose

66. Id. at 350 .

67. United States v. Garcia-Perez, 190 F. App'x 461 (6th Cir. 2006).

68. Commonwealth v. Padilla, No. 13 WAP 2006, slip op. (Ct. of Comm. Pleas of Blair County Aug. 1, 2006).

69. Garcia-Perez, 190 F. App'x at 462-63.

70. Id. at 463 . 
less than a month after Sanchez-Llamas, the Sixth Circuit first addressed the recent Supreme Court decision. The court noted that the Supreme Court assumed without deciding that the VCCR created individually enforceable rights. $^{71}$ Therefore, the Supreme Court "did not answer the question of whether the [VCCR] created enforceable individual rights. ${ }^{\prime 72}$ In the absence of a rule of decision by the Supreme Court, the Sixth Circuit applied its existing precedent to resolve the current controversy.

The Sixth Circuit previously held in United States v. Emuegbunam ${ }^{73}$ that Article 36 did not "create a right for a detained foreign national to consult with the diplomatic representatives of his nation that the federal courts can enforce." 74 In Emuegbunam, a Nigerian citizen was arrested for conspiracy to import heroin into the United States. ${ }^{75}$ The Emuegbunam court observed that international treaties do not generally create privately enforceable rights. ${ }^{76}$ In Garcia-Perez, the Sixth Circuit offered the following analysis on treaty obligations generally:

\begin{abstract}
A treaty is primarily a compact between independent nations. It depends for the enforcement of its provisions on the interest and honor of the governments which are parties to it. If these fail, its infraction becomes the subject of international negotiations and reclamation, so far as the injured parties choose to seek redress, which may in the end be enforced by actual war. It is obvious that with all this the judicial courts have nothing to do and can give no redress. ${ }^{77}$
\end{abstract}

Therefore, the Sixth Circuit characterized Article 36 as granting signatory nations certain diplomatic rights against other signatory nations. It rejected the individually enforceable rights that the Supreme Court in Sanchez-Llamas "assume[d], without deciding" existed $;{ }^{78}$ rather, it interpreted Article 36 as not providing "any judicially enforceable right of consultation between a detained foreign national and the consular representatives of his nation." "79 The Sixth Circuit in Emuegbunam cited the preamble of the VCCR in support of its holding: "[T] he purpose of such privileges and immunities is not to benefit individuals but to ensure the efficient performance of functions by consular

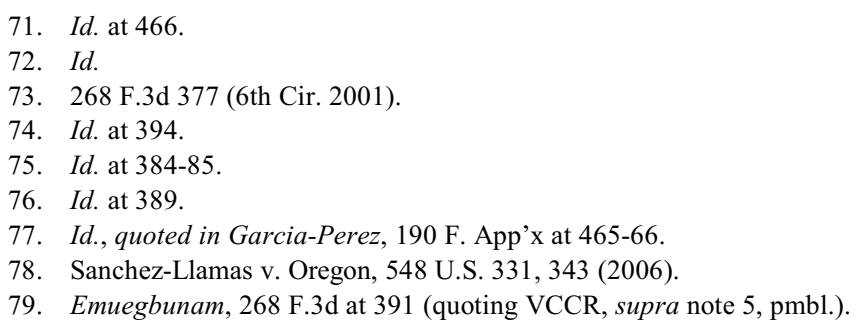


posts on behalf of their respective States." ${ }^{80}$ Therefore, contracting states have merely granted rights to each other; informing detainees of their "right" to consular notice has simply been a means of implementing these treaty obligations between the states. ${ }^{81}$ The Sixth Circuit also noted the position of the State Department that the VCCR "does not create individual rights."

By holding that Article 36 does not confer any individual rights, the Sixth Circuit did what the Supreme Court in Sanchez-Llamas was unwilling to do: mount a substantive attack on Article 36. Because Sanchez-Llamas ultimately failed to decide whether Article 36 created individually enforceable rights, ${ }^{83}$ the Sixth Circuit holding that it does not create such rights was a permissible interpretation. The holding also injected an institutional competency argument into the Article 36 debate, which the Supreme Court previously alluded to when it addressed proper techniques for vindicating Article 36 rights. ${ }^{84}$

The VCCR, as a valid treaty, "binds the States pursuant to the Supremacy Clause, and ... the States therefore must recognize the force of the treaty in the course of adjudicating the rights of litigants." ${ }^{\circ 5}$ Under the Federal Constitution, the President has the power, with the advice and consent of the Senate, to enter into international treaties. ${ }^{86}$ When the United States ratified the VCCR, it did so "with the expectation that it would be interpreted according to its terms." " Therefore, the Court's authority to create a "judicial remedy applicable in state court must lie, if anywhere, in the treaty itself." 88 Inferentially, the Court deemed a judicial remedy inappropriate given the absence of remedial language in the treaty itself.

The Supreme Court has thus made it effectively irrelevant whether Article 36 creates individually enforceable rights since there is no potential remedy. In Sanchez-Llamas, the Supreme Court implicitly addressed ${ }^{89}$ the institutional

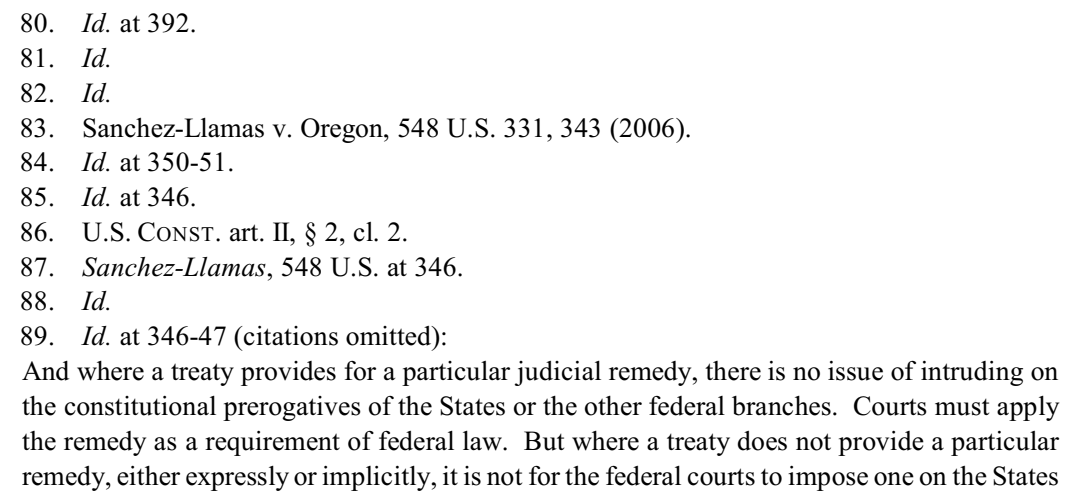


competency concerns that the Sixth Circuit in Emuegbunam explicitly addressed. $^{90}$ Even if courts are wary of usurping their boundaries of institutional competency, they might feel comfortable addressing the import of Article 36 in light of the President's ambivalent declaration that the United States will "discharge its international obligations" under the VCCR. ${ }^{11}$

\section{Commonwealth V. Padilla}

A second post-Sanchez-Llamas case to address Article 36 derives from state court. In August of 2006, the Supreme Court of Pennsylvania entertained its first appellate level challenge to Article 36 after SanchezLlamas. ${ }^{92}$ Commonwealth v. Padilla is informative because of the procedural posture in which the Article 36 claim arose. In Padilla, a Mexican national was charged with triple homicide and other violations. ${ }^{93}$ In contrast to the other cases addressed thus far, the Article 36 claim in Padilla arose before trial. ${ }^{94}$ Therefore, rather than focusing on procedural default and other postconviction proceedings, the case offers insight into how an Article 36 claim might proceed before or during trial.

As the case reveals, Article 36 claims often arise in trial courts completely unfamiliar with the VCCR. The actions of the trial court in Padilla underscore the obstacles an Article 36 claimant faces when seeking recognition of Article 36 rights in such a "foreign" environment. Because Sanchez-Llamas effectively eliminates post-conviction remedies for Article

\footnotetext{
through lawmaking of their own. Id. at 350 :

Finally, suppression is not the only means of vindicating Vienna Convention rights. A defendant can raise an Article 36 claim as part of a broader challenge to the voluntariness of his statements to police. If he raises an Article 36 violation at trial, a court can make appropriate accommodations to ensure that the defendant secures, to the extent possible, the benefits of consular assistance. Of course, diplomatic avenues - the primary means of enforcing the Convention-also remain open.

90. Under this view, the contracting VCCR states are granting each other rights vis-à-vis their executive branches. See United States v. Emuegbunam, 268 F.3d 377, 392 (6th Cir. 2001).

91. Sanchez-Llamas, 548 U.S. at 355 ("Although the United States has agreed to 'discharge its international obligations' in having state courts give effect to the decision in Avena, it has not taken the view that the ICJ's interpretation of Article 36 is binding on our courts." (citations omitted)). In its 2008 term, the Supreme Court decided Medellin v. Texas, 128 S.C. 1346 (2008). The Court held that Article 36 is not self-executing, reasoning that the Vienna Treaty requires implementing legislation for enforcement.

92. See Commonwealth v. Padilla, 908 A.2d 265 (Pa. 2006) (mem.) (per curiam).

93. Id.

94. $I d$.
} 
36 violations, when recognition of these rights falters at the trial court level, the obstacles encountered in Padilla risk becoming irremediable.

In Padilla, the defendant was a Mexican national who faced capital homicide charges in connection with a shooting in Blair County, Pennsylvania. ${ }^{95}$ Article 36 became an issue when Mexico became aware that the defendant Mexican national was potentially facing the death penalty; Mexico then attempted to intervene on his behalf. ${ }^{96}$ Although this procedural posture strays from the "consular notice" scenario found in SanchezLlamas - that is, rather than the foreign national attempting to invoke his Article 36 rights, it is the foreign government attempting to perform its Article 36 duties - it nonetheless illustrates how state trials courts confront Article 36 issues generally.

Padilla involved two separate issues before the Supreme Court of Pennsylvania. The first was an appeal by Mexico of an order by the trial court prohibiting its involvement in the defendant's trial. ${ }^{97}$ Mexico then sought an application for stay to postpone the trial until the Court could resolve the parties' underlying Article 36 rights. $^{98}$ In a decision without a published opinion, the Court quashed the underlying appeal as interlocutory and dismissed as moot the Emergency Application for Stay. ${ }^{99}$ The result was similar to that predicted by Sanchez-Llamas in that any potential Article 36 violations in Padilla were relegated to subsidiary post-conviction claim status. Although the Supreme Court of Pennsylvania in Padilla did not publish an opinion with its decision, what follows is a hypothetical analysis (in the form of a memorandum) in which the court might have engaged, or how a similar court might address a comparable situation.

\section{Hypothetical Article 36 Memorandum Analysis in Padilla}

Pursuant to the VCCR and the Consular Convention between the United Mexican States and the United States of America (U.S.-Mexico Convention), the Mexican Government attempted to intervene on Mr. Padilla's behalf. ${ }^{100}$

95. Commonwealth v. Padilla, No. 13 WAP 2006, slip op. at 3 (Ct. of Comm. Pleas of Blair County Aug. 1, 2006).

96. Id.

97. Padilla, 908 A.2d 265.

98. Id.

99. Id.

100. The Commonwealth noted in its reply to Mexico's application for stay that the U.S. Supreme Court in Sanchez-Llamas v. Oregon recently interpreted the VCCR as "not guarantee[ing] defendants any assistance at all. The provision secures only a right of foreign nationals to have their consulate informed 
After several attempts by Mexico to address the trial court concerning Mr. Padilla's rights, the Court of Common Pleas issued an order on May 18, 2006, preventing the Mexican Government from addressing the court in any capacity. Mexico appealed and we asked the parties to submit briefs concerning Mexico's attempted court intervention. ${ }^{101}$ Meanwhile, trial court proceedings continued, with the trial set to begin the week before briefs are due in this Court on the pending appeal. Instantly, Mexico asks for a stay of the trial court proceedings. met: ${ }^{102}$

In considering an application for stay, the following four prongs must be

(1) The petitioner makes a strong showing that he is likely to prevail on the merits; ${ }^{103}$

of their arrest or detention - not to have their consulate intervene, or to have law enforcement authorities cease their investigation pending any such notice or intervention." Sanchez-Llamas v. Oregon, 548 U.S. 331, 349 (2006). However, Sanchez-Llamas is distinguishable from the current case because the Supreme Court only addressed the rights of the defendant and only in the context of consular notification. The Commonwealth ignores the language of the VCCR granting the sending state, as opposed to the defendant, the right to "intervene":

$[C]$ onsular officers shall have the right to visit a national of the sending State who is in prison, custody or detention, to converse and correspond with him and to arrange for his legal representation. They shall also have the right to visit any national of the sending State who is in prison, custody or detention in their district in pursuance of a judgment. Nevertheless, consular officers shall refrain from taking action on behalf of a national who is in prison, custody or detention if he expressly opposes such action.

VCCR, supra note 5, art. 36, § 1(c). Separate from the VCCR, the U.S.-Mexico Convention apparently contemplates an avenue for the sending state to address the authorities of the receiving state:

Consular officers of either High Contracting Party may, within their respective consular districts, address the authorities, National, State, Provincial or Municipal, for the purpose of protecting the nationals of the State by which they were appointed in the enjoyment of rights accruing by treaty or otherwise. Complaint may be made for the infraction of those rights. Consular Convention Between the United States of America and the United Mexican States, U.S.-Mex., Aug. 12, 1942, art. VI, § 1, 57 Stat. 800, 125 U.N.T.S. 302.

101. Although the United States in 2005 withdrew from the Optional Protocol of the VCCR that granted the International Criminal Court limited jurisdiction in capital cases, other aspects of the VCCR remain in force. Sanchez-Llamas, 548 U.S. at 338-39. The Court in Sanchez-Llamas held that suppression is an inappropriate remedy for VCCR violations and that states may apply their regular procedural default rules to VCCR claims. Id. at 358-59. Mexico is apparently still allowed to offer "consular assistance" and perform various consultation functions. It is considerably less clear whether Mexico is entitled to independently address the court and provide courtroom assistance concurrent to representation by approved counsel of record.

102. Pa. Pub. Util. Comm'n v. Process Gas Consumers Group, 467 A.2d 805, 808-09 (Pa. 1983).

103. It should be noted that the "requirement that the applicant for a stay show that it is likely he will prevail on the merits should not be an inflexible rule. This criterion must be considered and weighed relative to the other three criteria." Id. at 809 n.8. Petitioner will have an opportunity to address the merits of alleged VCCR and treaty violations when the case is submitted on briefs. 
(2) The petitioner has shown that without the requested relief, he will suffer irreparable injury;

(3) The issuance of a stay will not substantially harm other interested parties in the proceedings; and

(4) The issuance of a stay will not adversely affect the public interest.

Petitioner fails to satisfy at least the second prong of the test, that of irreparable injury. Perhaps unfortunate from the perspective of judicial economy considering the proximity of the appeal to the trial, claims of alleged VCCR and U.S.-Mexico Convention violations can nevertheless be raised on appeal or in a subsequent ineffective assistance of counsel proceeding. ${ }^{104}$ Although it remains possible that both Mexico and Mr. Padilla have legitimate treaty grievances, neither party risks irreparable harm if the trial proceeds. ${ }^{105}$

In Sanchez-Llamas, the United States Supreme Court held that procedural default rules apply to defendants who fail to raise alleged VCCR violations in state court and later attempt to raise them at the federal level. ${ }^{106}$ However, the risk of procedural default does not appear to be implicated in this case, which indicates a lack of irreparable harm. Through its pending appeal, Mexico has provided Mr. Padilla with actual notice of potential treaty violations, violations that Mr. Padilla presumably could raise through his own counsel or, if counsel fails to do so, as part of an ineffective assistance of counsel claim at a subsequent post-conviction hearing. In one of the few appellate level cases in Pennsylvania addressing alleged VCCR violations, the superior court noted that an issue is waived only if a defendant could have raised an issue but failed to do so either before trial, at trial, on direct appeal, or during a postconviction proceeding. ${ }^{107}$ Therefore, even after trial, Mexico and Mr. Padilla will still be able to seek relief for alleged VCCR violations. Accordingly, the application for stay cannot be said to establish irreparable harm. ${ }^{108}$

104. Commonwealth v. Quaranibal, 763 A.2d 941, 944 (Pa. Super. Ct. 2000).

105. See id.

106. Sanchez-Llamas, 548 U.S. at 360.

107. Quaranibal, 763 A.2d at 944.

108. At a glance, 210 PA. Code $\S 1701$ (a) (2004) seems to invite application here. It reads as follows: "Except as otherwise prescribed by these rules, after an appeal is taken or review of a quasijudicial order is sought, the trial court or other government unit may no longer proceed further in the matter." While Mexico asserts that Mr. Padilla seeks its assistance in addressing Blair County authorities, Brief for Petitioner at 7, Mexico itself, nevertheless, is not counsel of record and is not currently a party to the case. Commonwealth v. Padilla, No. 05 CR 2273, slip op. at 5-6 (Ct. of Com. Pleas of Blair County May 18, 2006). Mexico cites Commonwealth v. Hall, 476 A.2d 7, 9 (Pa. Super. Ct. 1984), in support of its reliance on $\S 1701$ (a). However, Hall involved a defendant who filed a pro se appeal. In contrast, here, Mr. Padilla has not filed an appeal on his own behalf, either through counsel of record or pro se. After a search of case law, there is no indication that an appeal by a non-party triggers automatic stay under $\S 1701(\mathrm{a})$. It is also 


\section{CONCLUSION}

The Supreme Court in Sanchez-Llamas envisioned the possibility of defendants raising Article 36 violations at trial, a time it felt that courts could still "make appropriate accommodations to ensure that the defendant secures, to the extent possible, the benefits of consular assistance."109 However, as Padilla and the hypothetical analysis of the case above illustrate, trial courts are sometimes unaware of Article 36 or unwilling to even entertain alleged violations. ${ }^{110}$ The Supreme Court of Pennsylvania implicitly approved of this "Article 36 ignorance" at the trial court level. ${ }^{111}$ It seems that the hypothetical analysis offered above includes the most viable option that remains open to pursue Article 36 violations in the face of an obstinate trial court. That is, Article 36 claims must be resigned to broader post-conviction proceedings, namely in the form of ineffective assistance of counsel proceedings or challenges to overall voluntariness. ${ }^{112}$

Because Sanchez-Llamas merely "assume[d], without deciding" "13 that the VCCR creates individually enforceable rights, Article 36 enforcement is left to individual states and individual courts. One possibility is what occurred in the Sixth Circuit, where the court recently sanctioned a previous determination that no such rights exist. ${ }^{114}$ Another result follows from Padilla, where a court apparently decided that Article 36 violations, even if enforceable, are not cognizable until incorporated into a broader postconviction challenge. While the Supreme Court reassures that such subordinate opportunity for Article 36 relief is "no slight to the Convention," 115 it seems unlikely that Article 36 will command anything more than indirect judicial recognition in the future. ${ }^{116}$

unclear whether Mexico seeks to intervene pursuant to state procedural rules or merely on an independent basis pursuant to treaty. These issues will likely be addressed on appeal.

109. Sanchez-Llamas v. Oregon, 548 U.S. 331, 350 (2006).

110. Commonwealth v. Padilla, No. 13 WAP 2006, slip op. at 7 (Ct. of Comm. Pleas of Blair County Aug. 1, 2006).

111. Commonwealth v. Padilla, 908 A.2d 265 (2006).

112. Sanchez-Llamas, 548 U.S. at 350.

113. Id. at 343 .

114. United States v. Garcia-Perez, 190 F. App'x 461, 464 (6th Cir. 2006); see also United States v. Emuegbunam, 268 F.3d 377, 394 (6th Cir. 2001).

115. Sanchez-Llamas, 548 U.S. at 360.

116. Id. at 350:

Leaving aside the suggestion that it is the role of police generally to advise defendants of their legal options, we think other constitutional and statutory requirements effectively protect 
The Supreme Court remains actively involved in the subject, as evidenced by its recent decision in Medellin v. Texas. ${ }^{117}$ Although the Court determined that Article 36 is not self-executing, it left the door open to legislative support, which could be the next chapter in this ongoing history. ${ }^{118}$ If Article 36 is to command general respect by U.S. authorities and enjoy widespread enforcement in U.S. courts, Congress would probably need to pass implementing legislation. After Medellin, this might lead to more uniform interpretation and encourage nationwide respect to Article 36 rights. While comity is characterized by the informal process of extending international courtesy, perhaps Article 36 would benefit from formal federalization. Heightened formality, while perhaps varying the international posture of the treaty, might lead to greater respect for the values the VCCR seeks to instill. It might also encourage reciprocal protection when Americans abroad find themselves detained by foreign governments. The goal of protecting Americans throughout the world could be advanced by protecting internationals within our own country. One would hope that a policy protecting Americans citizens throughout the world would not encounter internal resistance from any branch of our own government.

the interests served, in Sanchez-Llamas' view, by Article 36. A foreign national detained on suspicion of crime, like anyone else in our country, enjoys under our system the protections of the Due Process Clause. Among other things, he is entitled to an attorney, and is protected against compelled self-incrimination. Article 36 adds little to these "legal options," and we think it unnecessary to apply the exclusionary rule where other constitutional and statutory protections . . . safeguard the same interests Sanchez-Llamas claims are advanced by Article 36.

117. 128 S. Ct. 1346 (2008).

118. Id. at $1373-75$. 